\title{
Response of Faba Bean to Phosphate Fertilizer and Weed Control on Nitisols of Ethiopian Highlands
}

\author{
Getachew Agegnehu*, Rezene Fessehaie \\ Holetta Agricultural Research Center, EARO \\ P.O. Box 2003, Addis Ababa, Ethiopia
}

Received: 1 February 2005. Accepted: 16 March 2006

\begin{abstract}
The effects of phosphorus fertilizer and weed control on yield and major yield components of faba bean (Vicia fa$b a$ L.) were studied on Nitisols of Ethiopian highlands. Factorial combinations of four levels of phosphorus fertilizer $\left(0,10,20\right.$ and $\left.30 \mathrm{~kg} \mathrm{P} \mathrm{ha}^{-1}\right)$ as triple super phosphate (TSP) and two levels of weeding (W1 = no weeding and $\mathrm{W} 2$ = hand weeding once six weeks after crop emergence) were laid out in randomized complete block design with three replications. Results indicated that highly significant positive responses of number of pods per plant, total biomass and seed yields of faba bean to phosphorus fertilizer and weeding treatments were noted. Phosphorus level $\times$ weed control interaction over three years significantly $(P \leq 0.05)$ affected faba bean seed yield at Rob Gebeya but not at Welmera. Phosphorus application at the rates of 10, 20 and $30 \mathrm{~kg} \mathrm{P}^{-1}$ hasulted in mean seed yield increases compared to the control of 20,41 and $53 \%$, respectively on the average of locations; 13,33 and $51 \%$, respectively at Welmera, and 26, 48 and 55\%, respectively at Rob Gebeya. Weeding once increased mean seed yields of faba bean by $25 \%$ on the average (35 and $17 \%$ at Welmera and Rob Gebeya, respectively) compared to unweeded check. Seed yield was positively correlated with total biomass and number of pods per plant $\left(\mathrm{r}=0.95^{* * *}\right.$ and $0.75^{* * *}$, respectively) at Welmera, and $\left(\mathrm{r}=0.94^{* * *}\right.$ and $0.55^{* *}$, respectively) at Rob Gebeya. The results of economic analysis indicated that the highest marginal rate of return was obtained from weeding once six weeks after crop emergence and application of $20 \mathrm{~kg} \mathrm{P} \mathrm{ha}{ }^{-1}$, which is economically the most feasible alternative on Nitisols of central Ethiopian highlands.
\end{abstract}

Key-words: Ethiopian highland, faba bean, Nitisol, phosphate fertilizer, weed control.

\section{Introduction}

Faba bean (Vicia faba L.) is the most important grain legume in Ethiopia in terms of area, production, source of protein and as a rotation crop ameliorating soil fertility. Despite the importance of the crop in the traditional farming systems, the yield is generally low due to several factors, among which poor soil fertility and inadequate plant nutrition, poor seedbed preparation, untimely sowing, sub-optimal weed control, and the lack of improved varieties are the major ones (Berhe et al., 1990; Ghizaw and Molla, 1994). Previous research results indicated that weed competition and soil fertility are major constraints of faba bean production (Ghizaw and Molla, 1994; Ghizaw et al., 2000).
The application of NP fertilizer significantly increased seed yields of faba bean (Tsigie and Woldeab, 1994; Ghizaw et al., 1999). Phosphorus is, in fact, the most important growth limiting nutrient factor for pulses including faba bean. Although blanket application of $18 / 20 \mathrm{~kg}$ $\mathrm{NP} \mathrm{ha} \mathrm{A}^{-1}$ in the form of diammonium phosphate (DAP) has been recommended for faba bean production in the country, this was not substantiated by research results (Ghizaw et al., 1999). Field trials using cv. CS20DK for high altitudes (> $2400 \mathrm{~m}$ ) and cv. NC58 for mid altitude (1900 to $2300 \mathrm{~m}$ ) showed that faba bean seed yield was significantly affected by $\mathrm{P}$ fertilizer applications (Ghizaw et al., 2000). The location by fertilizer interaction indicated that the application of $\mathrm{P}$ significantly increased faba bean seed 
yield (Ghizaw et al., 2000). In all cases a positive linear response of faba bean seed yield to $P$ fertilization was obtained. It was also found that response of faba bean to $\mathrm{P}$ application was dependent on the residual $P$ fertility level of the soil (Hebblethwaite et al., 1983; Agegnehu et al., 2003). Absence of fertilizer response across locations is related to the residual fertility level of nutrients, while negative response could be related to activities of soil microorganisms, which need further researches (Hebblethwaite et al., 1983; Ghizaw et al., 2000).

The productivity of food legumes is constrained by low soil $\mathrm{pH}$ and the consequent low $\mathrm{P}$ availability. Acid Nitisols are of wide occurrence in the highlands of Ethiopia where the rainfall intensity is high and the land has been under cultivation for many years. These soils, by and large, have $\mathrm{pH}$ values of less than 5.5, thereby resulting in low faba bean yields in comparison to other faba bean growing areas of the country. The low yields in such soils could mainly be due to either the deficiency of nutrients, such as P, Ca and Mg (Bekele and Höfner, 1993; Agegnehu and Sommer, 2000), or to low pH and toxicity of Al, Fe and Mn (Sharma et al., 1990).

Inadequate and untimely weed control operation is one of the crucial factors causing low yields of faba bean. Since labour for weeding the crops is usually competing with weeding of tef and wheat, many fields remain unweeded or hand weeding occurs after weeds have already reduced the yield potential of crops. Conditions favourable to the growth of weeds and poor weed control practices during critical weed-crop competition periods are major causes of the problem. Fessehaie (1994) reported that faba bean suffered significant yield loss of about $24 \%$ due to weed competition. The crop is highly sensitive to weed competition from the early establishment to early flowering stage and it requires weed control during this critical period. Moreover, usage of fertilizer is also considered as one factor to increase weed growth and its application need to be combined with timely and optimum hand weeding recommendations. Since the interaction effects of fertilizer and weed control on faba bean are not well studied, this experiment is needed to establish practical recommendations for the area. Therefore, the objectives of the study were to determine the effects of phosphorus and weed control, eco- nomic dose of $\mathrm{P}$, and optimum combination of $\mathrm{P}$ and weed control for faba bean production on Nitisols of highlands of Ethiopia.

\section{Materials and methods}

\subsection{Experimental site}

The trial sites were located at Welmera and Rob Gebeya areas of west Shewa, highlands of Ethiopia, between $09^{\circ} 03^{\prime} \mathrm{N}$ latitude and $38^{\circ} 30^{\prime} \mathrm{E}$ longitude at an altitude of about $2400 \mathrm{~m}$ above sea level. The rainfall is bimodal with long-term average annual rainfall of $1100 \mathrm{~mm}$, about $85 \%$ of which from June to September and the rest from January to May and average minimum and maximum air temperatures of 6.1 and $21.9{ }^{\circ} \mathrm{C}$, respectively. The environment is seasonally humid and the major soil type of the trial sites is Eutric Nitisol (FAO classification). Soil physical and chemical properties were determined for samples taken during planting. These included soil texture, soil $\mathrm{pH}$, organic carbon (OC), $\mathrm{NH}_{4}^{-}$ $\mathrm{N}, \mathrm{NO}_{3}-\mathrm{N}$, total $\mathrm{N}$, available $\mathrm{P}$, exchangeable cations (EC) and cation exchange capacity (CEC) of the experimental fields that are shown in Table 1.

\subsection{Experimental set-up}

The experiment was conducted under rain-fed conditions to determine the effects of phosphate fertilizer and weed control practices and their interaction on faba bean for three consecutive years (2001-2003 main cropping seasons). Experimental fields were ploughed two times before planting by using oxen drawn implements. The design employed was randomized complete block with three replications. The treatments included factorial combination of four levels of phosphorus fertilizer $\left(0,10,20\right.$ and $\left.30 \mathrm{~kg} \mathrm{P}^{-1}\right)$ and two levels of weeding $(\mathrm{W} 1=$ no weeding and $\mathrm{W} 2$ = hand weeding once six weeks after crop emergence). Phosphorus fertilizer was applied at planting as triple super-phosphate. Experimental plots received blanket application of $20 \mathrm{~kg} \mathrm{~N} \mathrm{ha}^{-1}$ as a starter dressing at planting in the form of urea. Disease or insect control chemicals were not used during the growth of faba bean.

An improved faba bean cultivar (CS20DK) was planted on plots of $5 \times 6 \mathrm{~m}$ at the rate of $200 \mathrm{~kg} \mathrm{ha}^{-1}$. Sowings were made from mid of 
Table 1. Physical and chemical soil characteristics $(0-20 \mathrm{~cm}$ depth) of the experimental sites at Welmera and Rob Gebeya.

\begin{tabular}{lccr}
\hline Parameter & Welmera & Rob Gebeya & Mean \\
\hline Clay (\%) & 58.5 & 53.6 & 56.1 \\
Silt (\%) & 25.7 & 31.5 & 28.6 \\
Sand (\%) & 15.8 & 14.9 & 15.4 \\
pH (1:1 H2O) & 4.3 & 5.1 & 4.7 \\
Organic carbon (\%) & 1.5 & 1.8 & 1.7 \\
$\mathrm{NH}_{4}-\mathrm{N}(\mathrm{ppm})$ & & 32.7 & \\
$\mathrm{NO}_{3}-\mathrm{N}(\mathrm{ppm})$ & & 16.7 & \\
Total N (g kg-1) & 1.7 & 2.2 & 1.9 \\
$\mathrm{P}(\mathrm{ppm})^{*}$ & 5.0 & 10.1 & 7.5 \\
$\mathrm{Na}\left(\mathrm{meq} 100 \mathrm{~g}^{-1}\right)$ & 0.1 & 0.1 & 0.1 \\
$\mathrm{~K}\left(\mathrm{meq} 100 \mathrm{~g}^{-1}\right)$ & 1.3 & 1.3 & 1.3 \\
$\mathrm{Ca}\left(\mathrm{meq} 100 \mathrm{~g}^{-1}\right)$ & 2.7 & 2.8 & 2.8 \\
Mg (meq100 g-1) & 2.1 & 2.3 & 2.2 \\
$\mathrm{CEC}\left(\mathrm{meq} 100 \mathrm{~g} \mathrm{~g}^{-1}\right)$ & 23.4 & 22.3 & 22.8 \\
\hline
\end{tabular}

"Bray II Method.

June to the last week of June depending on the onset of rainfall. Tef (Eragrostis tef Zucc.) was the preceding crop in 2001, wheat in 2002 and barley in 2003 in Welmera, and in Rob Gebeya wheat in 2001 and 2002 and barley in 2003. Agronomic parameters collected were plant stand count $\mathrm{m}^{-2}$ at complete emergence, plant height (average of ten plants), weed dry weight at weeding and harvesting of plants, number of pods per plant and seeds per pod (average of ten plants), total aboveground biomass and seed yields and thousand seed weight. To estimate total biomass and seed yields of faba bean a $12 \mathrm{~m}^{2}$ sample was harvested from each plot between the last week of October and mid November. Data on weeding (labour man-days), fertilizer and grain prices were collected. The harvested materials were sun-dried and manually threshed. After threshing, seeds were cleaned, weighed and adjusted at the $10 \%$ moisture level. Total biomass and seed yields recorded on plot basis were converted to $\mathrm{kg} \mathrm{ha}^{-1}$ for statistical analysis.

\subsection{Data analysis}

The data were subjected to analysis of variance using the SAS statistical package version 8.2 (SAS Institute Inc., 2001). The total variability for each trait was quantified using pooled analysis of variance over years based on the following model.

$$
\begin{aligned}
\mathrm{T}_{\mathrm{ijk} \mathrm{k}}=\mu & \left.+\mathrm{Y}_{\mathrm{i}+} \mathrm{R}_{\mathrm{j}(\mathrm{i})}+\mathrm{P}_{\mathrm{k}}+\mathrm{W}_{\mathrm{l}}+\mathrm{YP}_{(\mathrm{ik})}+\mathrm{YW}_{(\mathrm{il}}\right) \\
& +\mathrm{PW}\left({ }_{\mathrm{kl}}\right)+\mathrm{YPW}\left({ }_{\mathrm{ikl}}\right)+\mathrm{e}_{\mathrm{ijkl}}
\end{aligned}
$$

Where $T_{\mathrm{ijkl}}$ is total observation, $\mu=$ grand mean, $Y_{i}=$ effect of the $i^{\text {th }}$ year, $R_{j(i)}$ is effect of the $j^{\text {th }}$ replication, $P_{k}$ is effect of the $k^{\text {th }}$ phosphorus level, $\mathrm{W}_{1}$ is effect of the $\mathrm{l}^{\text {th }}$ weed control, YP, YW, PW and YPW are the interactions, and $\mathrm{e}_{\mathrm{ijkl}}$ is the variation due to random error. Results were presented as means, and 5\% level of significance was used in order to establish the differences among the means. Orthogonal contrasts were performed to calculate the linear, quadratic and cubic coefficients. Coefficients of correlation were also performed using the standard procedures from SAS programs at $P \leq$ $0.05, P \leq 0.01$ and $P \leq 0.001$.

Besides, to investigate the economic feasibility of the treatments, partial budget, dominance and marginal analyses were conducted. The average yield was adjusted downwards by $15 \%$ to reflect the difference between the experimental yield and the expected yield of farmers from the same treatment. This is because, experimental yields, even from on-farm experiments under representative conditions, are often higher than the yields that farmers could expect using the same treatments. The three years (2001-2003) average price of faba bean was used to convert the adjusted yields into gross field benefits. The costs of fertilizer and weeding were also taken from the study areas.

\section{Results and discussion}

\subsection{Crop growth and yield}

Total aboveground biomass and seed yield of faba bean significantly $(P \leq 0.001)$ responded to $P$ fertilizer application and weed control both at Welmera and Rob Gebeya (Table 2). Thousandseed weight of faba bean was significantly $(P \leq$ 0.05 ) affected by $\mathrm{P}$ fertilizer application and weed control. Other agronomic attributes like plant height, number of pods per plant and seeds per pod were also significantly different among levels of $\mathrm{P}$ fertilization at both locations (Table 3). Similarly, weed control significantly affected plant height, number of pods per plant and seeds per pod at Welmera. Total dry matter of broad-leaf and grass weeds at weeding and harvesting were also significantly $(P \leq$ $0.001)$ affected by $P$ fertilizer application at both locations. However, weed control had only a significant $(P \leq 0.001)$ effect on the total weed bio- 
Table 2. Mean biomass yield (BY), seed yield (SY) and thousand seed weight (TSW) of faba bean response to P fertilizer and weed control at Welmera and Rob Gebeya, 2001-2003.

\begin{tabular}{|c|c|c|c|c|c|c|}
\hline \multirow[t]{2}{*}{ Factors } & \multicolumn{3}{|c|}{ Welmera (A) } & \multicolumn{3}{|c|}{ Rob Gebeya (B) } \\
\hline & $\begin{array}{c}\text { BY } \\
\left(\mathrm{kg} \mathrm{ha}^{-1}\right)\end{array}$ & $\begin{array}{c}\mathrm{SY} \\
\left(\mathrm{kg} \mathrm{ha}^{-1}\right)\end{array}$ & $\begin{array}{c}\text { TGW } \\
(\mathrm{g})\end{array}$ & $\begin{array}{c}\text { TBY } \\
\left(\mathrm{kg} \mathrm{ha}^{-1}\right)\end{array}$ & $\begin{array}{c}\mathrm{SY} \\
\left(\mathrm{kg} \mathrm{ha}^{-1}\right)\end{array}$ & $\begin{array}{c}\text { TSW } \\
(\mathrm{g})\end{array}$ \\
\hline \multicolumn{7}{|l|}{$\mathrm{P}\left(\mathrm{kg} \mathrm{ha}^{-1}\right)$} \\
\hline 0 & $3083 \mathrm{c} \dagger$ & $1165 \mathrm{c}$ & $512 \mathrm{ab}$ & $2771 \mathrm{~d}$ & $1358 \mathrm{c}$ & $513 \mathrm{~b}$ \\
\hline 10 & $3358 \mathrm{bc}$ & $1314 \mathrm{c}$ & $500 \mathrm{~b}$ & $3582 \mathrm{c}$ & $1710 \mathrm{~b}$ & $528 \mathrm{a}$ \\
\hline 20 & 3848 b & $1545 \mathrm{~b}$ & $513 \mathrm{ab}$ & $4193 \mathrm{~b}$ & $2013 \mathrm{a}$ & $531 \mathrm{a}$ \\
\hline 30 & $4584 \mathrm{a}$ & $1763 \mathrm{a}$ & $522 \mathrm{a}$ & $4480 \mathrm{a}$ & $2101 \mathrm{a}$ & $530 \mathrm{a}$ \\
\hline F-probability & $* * *$ & $* * *$ & * & $* * *$ & $* * *$ & $*$ \\
\hline Linear & $* * *$ & $* * *$ & NS & $* * *$ & $* * *$ & * \\
\hline Quadratic & NS & NS & NS & $*$ & $* *$ & NS \\
\hline Cubic & NS & NS & NS & NS & NS & NS \\
\hline \multicolumn{7}{|l|}{ Weeding (W) } \\
\hline Unweeded & $3233 \mathrm{~b}$ & $1231 \mathrm{~b}$ & $517 \mathrm{a}$ & $3536 \mathrm{~b}$ & $1657 \mathrm{~b}$ & $517 \mathrm{~b}$ \\
\hline Once weeded & $4204 \mathrm{a}$ & $1662 \mathrm{a}$ & $506 \mathrm{~b}$ & 3977 a & $1934 \mathrm{a}$ & $534 \mathrm{a}$ \\
\hline F-probability & $* * *$ & $* * *$ & $*$ & $* * *$ & $* * *$ & $* *$ \\
\hline $\mathrm{P} \times \mathrm{W}$ & NS & NS & NS & NS & * & NS \\
\hline CV (\%) & 22.6 & 18.3 & 4.9 & 11.2 & 10.0 & 3.9 \\
\hline
\end{tabular}

$\dagger$ Means in a column with the same letter are not significantly different $(P<0.05)$.

*,**,***** Significant at $P \leq 0.05, P \leq 0.01$ and $P \leq 0.001$, respectively; NS $=$ Not significant.

Table 3. Mean plant height (PH), number of pods per plant (PPP) and seeds per pod (SPP) of faba bean as influenced by $\mathrm{P}$ fertilizer and weed control at Welmera and Rob Gebeya, 2001-2003.

\begin{tabular}{|c|c|c|c|c|c|c|}
\hline \multirow[t]{2}{*}{ Factors } & \multicolumn{3}{|c|}{ Welmera } & \multicolumn{3}{|c|}{ Rob Gebeya } \\
\hline & $\mathrm{PH}(\mathrm{cm})$ & PPP (n.) & SPP (n.) & $\mathrm{PH}(\mathrm{cm})$ & PPP (n.) & SPP (n.) \\
\hline \multicolumn{7}{|l|}{$\mathrm{P}\left(\mathrm{kg} \mathrm{ha}^{-1}\right)$} \\
\hline 0 & $117.3 \mathrm{~b} \dagger$ & $5.9 \mathrm{~b}$ & $2.5 \mathrm{~b}$ & $100.4 \mathrm{~b}$ & $6.84 \mathrm{~b}$ & $2.3 \mathrm{~b}$ \\
\hline 10 & $118.9 \mathrm{~b}$ & $6.8 \mathrm{ab}$ & $2.5 \mathrm{~b}$ & $103.4 \mathrm{~b}$ & $7.76 \mathrm{~b}$ & $2.5 \mathrm{a}$ \\
\hline 20 & $127.6 \mathrm{a}$ & $7.7 \mathrm{a}$ & $2.7 \mathrm{a}$ & $109.8 \mathrm{a}$ & $9.38 \mathrm{a}$ & $2.6 \mathrm{a}$ \\
\hline 30 & $129.6 \mathrm{a}$ & $7.8 \mathrm{a}$ & $2.6 \mathrm{ab}$ & $112.3 \mathrm{a}$ & $9.6 \mathrm{a}$ & $2.5 \mathrm{a}$ \\
\hline F-probability & $* *$ & $* * *$ & $*$ & $* * *$ & $* * *$ & $* *$ \\
\hline Linear & $* * *$ & $* * *$ & $*$ & $* * *$ & $* * *$ & $*$ \\
\hline Quadratic & NS & NS & NS & NS & NS & $* *$ \\
\hline Cubic & NS & NS & $*$ & NS & NS & NS \\
\hline \multicolumn{7}{|l|}{ Weeding (W) } \\
\hline Unweeded & $120.3 b$ & $6.2 \mathrm{~b}$ & $2.2 \mathrm{~b}$ & 107.8 & $8.0 \mathrm{~b}$ & 2.5 \\
\hline Once weeded & $126.4 \mathrm{a}$ & $7.9 \mathrm{a}$ & $2.7 \mathrm{a}$ & 105.3 & $8.8 \mathrm{a}$ & 2.4 \\
\hline F-probability & $*$ & $* * *$ & $* *$ & NS & $*$ & NS \\
\hline $\mathrm{P} \times \mathrm{W}$ & NS & NS & NS & NS & NS & NS \\
\hline CV (\%) & 9.3 & 20.1 & 7.3 & 7.2 & 21.2 & 9.0 \\
\hline
\end{tabular}

$\dagger$ Means in a column with the same letter are not significantly different $(P \leq 0.05)$.

*,**,***** Significant at $P \leq 0.05, P \leq 0.01$ and $P \leq 0.001$, respectively; NS $=$ Not significant.

mass of both weed types at weeding at Welmera. In case of Rob Gebeya, total dry matter of grass weeds (GW) was significantly affected at harvesting only (Table 4).

The highest number of pods per plant, total biomass and seed yields of faba bean were recorded from the application of $30 \mathrm{~kg} \mathrm{P} \mathrm{ha}^{-1}$
(Tables 2 and 3). However, statistically significant $(P \leq 0.05)$ yield difference was not observed between the rate of $20 \mathrm{~kg} \mathrm{P} \mathrm{ha}^{-1}$ and 30 $\mathrm{kg} \mathrm{P} \mathrm{ha-1}$ at Rob Gebeya. This is supported by the results of fertilizer trials at different locations of central highlands of Ethiopia (Tsigie and Woldeab, 1994; Ghizaw et al., 1999). The ap- 
Table 4. Phosphorus fertilizer and weed control effects on mean dry matter of broad-leaf (BLW) and grass weeds (GW) at Welmera and Rob Gebeya, 2001-2003.

\begin{tabular}{|c|c|c|c|c|c|c|c|c|}
\hline \multirow[b]{2}{*}{ Factors } & \multicolumn{4}{|c|}{ Welmera } & \multicolumn{4}{|c|}{ Rob Gebeya } \\
\hline & $\begin{array}{c}\text { BLW (g) at } \\
\text { weeding }\end{array}$ & $\begin{array}{l}\text { BLW }(g) \text { at } \\
\text { harvesting }\end{array}$ & $\begin{array}{c}\mathrm{GW}(\mathrm{g}) \text { at } \\
\text { weeding }\end{array}$ & $\begin{array}{l}\mathrm{GW}(\mathrm{g}) \text { at } \\
\text { harvesting }\end{array}$ & $\begin{array}{c}\text { BLW (g) } \\
\text { at weedingat }\end{array}$ & $\begin{array}{c}\text { BLW }(g) \\
\text { harvesting }\end{array}$ & $\begin{array}{l}\text { GW (g)at } \\
\text { weeding }\end{array}$ & $\begin{array}{l}\mathrm{GW}(\mathrm{g}) \text { at } \\
\text { harvesting }\end{array}$ \\
\hline \multicolumn{9}{|l|}{$\mathrm{P}\left(\mathrm{kg} \mathrm{ha}^{-1}\right)$} \\
\hline 0 & $72.1 \mathrm{a} \dagger$ & 549.9 a & $3.9 \mathrm{c}$ & $105.6 \mathrm{a}$ & $18.9 \mathrm{c}$ & $74.3 \mathrm{c}$ & $5.3 \mathrm{c}$ & $116.4 \mathrm{~b}$ \\
\hline 10 & $30.4 \mathrm{c}$ & $162.1 \mathrm{~d}$ & $8.9 \mathrm{~b}$ & $27.4 \mathrm{c}$ & $24.1 \mathrm{bc}$ & $89.3 \mathrm{bc}$ & $6.5 \mathrm{bc}$ & $150.3 \mathrm{ab}$ \\
\hline 20 & $44.6 \mathrm{~b}$ & $396.1 \mathrm{~b}$ & $7.8 \mathrm{~b}$ & $44.6 \mathrm{~b}$ & $26.0 \mathrm{~b}$ & $117.5 \mathrm{a}$ & $8.7 \mathrm{ab}$ & $186.1 \mathrm{a}$ \\
\hline 30 & $35.5 \mathrm{bc}$ & $263.6 \mathrm{c}$ & $11.5 \mathrm{a}$ & $33.0 \mathrm{c}$ & $31.9 \mathrm{a}$ & $95.6 \mathrm{~b}$ & $10.8 \mathrm{a}$ & $126.6 \mathrm{~b}$ \\
\hline F-probability & $* * *$ & *** & $* *$ & $* * *$ & $* *$ & $* *$ & $* *$ & $* *$ \\
\hline Linear & $* * *$ & $* * *$ & $* * *$ & $* * *$ & $* * *$ & NS & $* * *$ & NS \\
\hline Quadratic & $* *$ & $* * *$ & NS & $* * *$ & NS & NS & NS & $* *$ \\
\hline Cubic & $* * *$ & $* * *$ & $* * *$ & $* * *$ & NS & $* *$ & NS & NS \\
\hline \multicolumn{9}{|l|}{ Weeding (W) } \\
\hline Unweeded & $50.1 \mathrm{a}$ & $438.4 \mathrm{a}$ & $7.2 \mathrm{~b}$ & $71.0 \mathrm{a}$ & 25.0 & 97.4 & 8.1 & $210.7 \mathrm{a}$ \\
\hline Once weeded & $41.3 \mathrm{~b}$ & $247.4 \mathrm{~b}$ & $8.8 \mathrm{a}$ & $34.4 \mathrm{~b}$ & 25.5 & 90.9 & 7.6 & $79.0 b$ \\
\hline F-probability & $*$ & *** & $*$ & $* * *$ & NS & NS & NS & $* * *$ \\
\hline $\mathrm{P} \times \mathrm{W}$ & $* *$ & $* * *$ & NS & $* *$ & NS & $* * *$ & $*$ & $* *$ \\
\hline CV (\%) & 20.5 & 12.6 & 19.8 & 14.2 & 17.6 & 17.8 & 22.4 & 20.3 \\
\hline
\end{tabular}

$\dagger$ Means in a column with the same letter are not significantly different $(P \leq 0.05)$.

***,**** Significant at $P \leq 0.05, P \leq 0.01$ and $P \leq 0.001$, respectively; NS $=$ Not significant.

plication of 23/20 kg N/P ha ${ }^{-1}$ produced the best seed yield of faba bean $\left(2.6 \mathrm{t} \mathrm{ha}^{-1}\right)$ at Kokate area of southern highland (Tsigie and Woldeab, 1994). It was also clear that response to P fertilizer was generally much greater by improved cultivars than it was by the local ones (Tsigie and Woldeab, 1994).

The application of $\mathrm{P}$ fertilizer at the rates of 10,20 and $30 \mathrm{~kg} \mathrm{P}^{\mathrm{Pa}} \mathrm{h}^{-1}$ resulted in a linear response with mean seed yield advantages of 20 , 41 and $53 \%$, respectively over locations, and 13 , 33 and $51 \%$, respectively at Welmera. However, at Rob Gebeya the same rates resulted in linear and quadratic responses with mean seed yield advantages of 26,48 and $55 \%$, respectively compared to the control (Table 2). The results revealed that the seed yields of faba bean showed consistently an increasing trend with increased rate of $\mathrm{P}$ fertilizer. Similar experimental findings on Nitisols and Alfisols of different locations also indicated that seed yields of faba bean linearly increased as the rate of P fertilizer consistently increased (Tsigie and Woldeab, 1994; Ghizaw et al., 1999; Agegnehu et al., 2003).

Analysis of variance over three years showed that there was a significant $(P \leq 0.05)$ $\mathrm{P}$ fertilizer level by weed control interaction ( $\mathrm{P}$ $\times$ W) for seed yield at Rob Gebeya but not at Welmera (Table 2). The highest mean seed yields (2044 and $2319 \mathrm{~kg} \mathrm{ha}^{-1}$ ) were obtained by the application of $30 \mathrm{~kg} \mathrm{P} \mathrm{ha}^{-1}$, respectively at Welmera and Rob Gebeya followed by 1828 and $2201 \mathrm{~kg} \mathrm{ha}^{-1}$ from $20 \mathrm{~kg} \mathrm{P} \mathrm{ha}{ }^{-1}$ accompanied with one properly timed hand weeding (Figure $1)$. The yield increments were higher by about 71 and $91 \%$, respectively at Welmera and 83 and $73 \%$, respectively at Rob Gebeya compared to the control treatment i.e., unfertilized and unweeded checks. A similar trend was noted across locations from the application of 30 and $20 \mathrm{~kg}$ $\mathrm{P} \mathrm{ha} \mathrm{A}^{-1}$ and once weeding in which the highest mean seed yield was $2181 \mathrm{~kg} \mathrm{ha}^{-1}$ followed by $2015 \mathrm{~kg} \mathrm{ha}^{-1}$, respectively, and respective yield advantages of 87 and $72 \%$ were obtained (Figure 1). Location by $\mathrm{P}$ levels and location by weed control interactions also significantly $(P \leq$ $0.05)$ affected seed yield. However, the interaction of location, $\mathrm{P}$ and weed control was not significant for yield. Seed yield was correlated significantly positively with plant height, total biomass, number of pods per plant and thousand seed weight $\left(\mathrm{r}=0.76^{* * * *}, 0.95^{* * * *} 0.75^{* * *}\right.$ and $0.36^{* * *}$, respectively) at Welmera, and $\left(\mathrm{r}=32^{*}, 0.94^{* * * *}\right.$, $0.55^{* *}$ and $0.54^{* *}$, respectively) at Rob Gebeya.

The results of soil analysis were found to be sub-optimal for the production of faba bean. As presented in Table 1 the soil $\mathrm{pH}$, available $\mathrm{P}$ and exchangeable cations were found to be by far below the optimum range. The soil $\mathrm{pH}$ and $\mathrm{P}$ values (4.3 and $5.0 \mathrm{ppm})$, respectively measured 

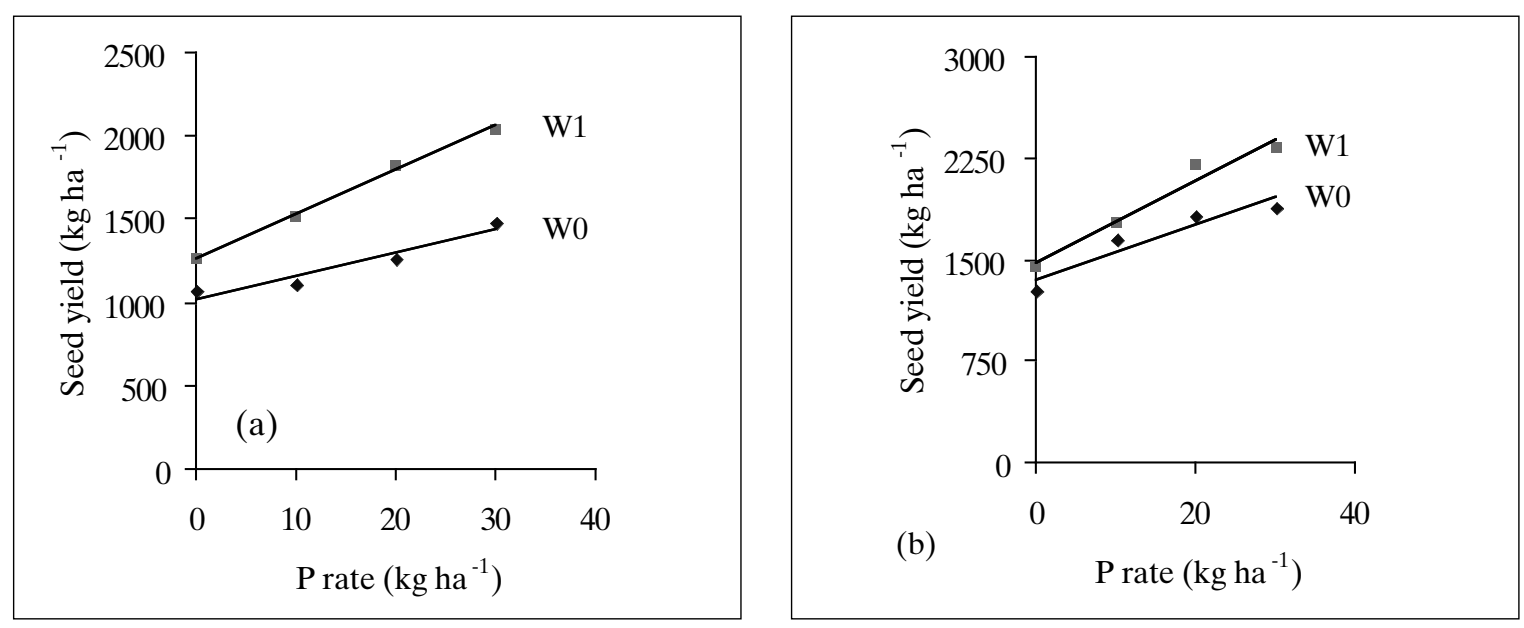

Figure 1. Faba bean seed yield as influenced by the interaction of phosphorus and weed control at (a) Welmera and (b) Rob Gebeya, $\bullet \mathrm{W} 0=$ Unweeded and $\square \mathrm{W} 1$ = Weeded, 2001-2003.

at Welmera were lower than those at Rob Gebeya (5.1 and 10.1). This had a direct relationship with the response of yield to applied $\mathrm{P}$, which was more at Rob Gebeya than at Welmera. In most cases soils whose $\mathrm{pH}$ is less than 5.5 are deficient in available $\mathrm{P}, \mathrm{Ca}$ and/or Mg (Cooke, 1986; Marschner, 1995; Agegnehu and Sommer, 2000). In such soils the proportion of $\mathrm{P}$ fertilizer that could immediately be available to a crop becomes inadequate and residues of the fertilizer may be released very slowly (Leon and Le Mare, 1990; Sikora et al., 1991).

Legume species differ widely in their ability to grow in soils of low P status. The study of Hocking et al. (1997) has explicated that white lupine and, to a lesser extent, pigeon pea can access soil $\mathrm{P}$ from a pool that is relatively inaccessible to other species. Mahler et al. (1988) also reported that in terms of nutrient availability pea, lentil, chickpea and faba bean grow best in soils with $\mathrm{pH}$ values between 5.7 and 7.2 and require between 12.9 and $34.4 \mathrm{~kg} \mathrm{P} \mathrm{ha}^{-1}$ for adequate yields which agrees with the findings of this study. When pulse crops are grown on soils whose $\mathrm{pH}$ values are less than 5.6 they give low yields (Mahler et al., 1988; Schubert et al., 1990). The application of $P$ fertilizer resulted in a linear response function (Figure 1). The regression line showed that mean seed yield of faba bean was most strongly correlated with $\mathrm{P}$ rate. This shows that the yield of faba bean has increased steadily as the level of $\mathrm{P}$ increased.
The optimum dose of $\mathrm{P}$ for attaining an economic yield of faba bean was found to be $20 \mathrm{~kg}$ $\mathrm{ha}^{-1}$.

Faba bean is a very sensitive crop to competition of both broad-leaf and grass weed species. The extent to which the yield is reduced by weeds depends not only on the weed species and density, but also on the period for which the crop is exposed to weeds. Several types of broad-leaf and grass weed species were identified in this experiment, among which Polygonum nepalense, Plantago lanceolata, Guizotia scabra, Galium spurium, Rumex abyssinicus, Phalaris paradoxa, Avena fatua, Spergula arvensis and Corrigiola capensis were the major species competing faba bean. At Welmera, the highest weed biomass was recorded from broadleaf species at weeding, but at Rob Gebeya the highest was recorded from grass weed species at harvesting. The density of weeds significantly responded to $\mathrm{P}$ fertilizer rate in which the weight of weed biomass at Rob Gebeya increased consistently as the $\mathrm{P}$ rate increased. Results showed that due to high vegetative growth of weeds from unweeded plots and late emerged weeds after weeding, the total weed biomass of both broad-leaf and grass weed species was higher at harvesting than at weeding.

Hand weeding once at six weeks after crop emergence increased mean seed yields of faba bean by $25 \%$ over locations, and 35 and $17 \%$ at Welmera and Rob Gebeya, respectively compared to the unweeded control treatment (Table 
Table 5. Coefficients of correlation among year $\times$ phosphorus $\times$ weed control interaction for agronomic traits in faba bean tested at four P and two weed control levels at Welmera (upper half diagonal) and at Rob Gebeya (lower half diagonal), 2001-2003.

\begin{tabular}{lcccccccccc}
\hline & PH & PPP & SPP & BY & GY & TSW & BLW1 & GW1 & BLW2 & GW2 \\
\hline PH & & $0.71^{* * *}$ & $0.28^{*}$ & $0.76^{* * *}$ & $0.76^{* * *}$ & $0.24^{*}$ & $-0.16^{\mathrm{NS}}$ & $0.13^{\mathrm{NS}}$ & $-0.39^{*}$ & $0.29^{\mathrm{NS}}$ \\
PPP & $0.30^{*}$ & & $0.36^{* *}$ & $0.77^{* * *}$ & $0.75^{* * *}$ & $0.13^{\mathrm{NS}}$ & $0.51^{*}$ & $0.28^{\mathrm{NS}}$ & $0.15^{\mathrm{NS}}$ & $-0.12^{\mathrm{NS}}$ \\
SPP & $0.37^{* *}$ & $0.15^{\mathrm{NS}}$ & & $21^{\mathrm{NS}}$ & $23^{*}$ & $-0.08^{\mathrm{NS}}$ & $0.10^{\mathrm{NS}}$ & $-0.36^{\mathrm{NS}}$ & $-0.35^{\mathrm{NS}}$ & $0.53^{* *}$ \\
TBY & $0.38^{* *}$ & $0.54^{* *}$ & $0.17^{\mathrm{NS}}$ & & $0.95^{* * *}$ & $0.37^{* *}$ & $-0.19^{\mathrm{NS}}$ & $0.30^{\mathrm{NS}}$ & $-0.43^{*}$ & $0.07^{\mathrm{NS}}$ \\
GY & $0.32^{*}$ & $0.55^{* *}$ & $0.10^{\mathrm{NS}}$ & $0.94^{* * *}$ & & $0.37^{* *}$ & $-0.18^{\mathrm{NS}}$ & $0.36^{\mathrm{NS}}$ & $-0.48^{*}$ & $0.10^{\mathrm{NS}}$ \\
TGW & $-0.01^{\mathrm{NS}}$ & $0.30^{*}$ & $-0.15^{\mathrm{NS}}$ & $0.48^{* *}$ & $0.54^{* *}$ & & 0.43 & $-0.31^{\mathrm{NS}}$ & $0.39^{*}$ & $-0.05^{\mathrm{NS}}$ \\
BLW1 & $0.32^{\mathrm{NS}}$ & $0.51^{* *}$ & $0.15^{\mathrm{NS}}$ & $0.62^{* *}$ & $0.61^{* *}$ & $0.55^{* *}$ & & $-0.52^{* *}$ & $0.63^{* *}$ & $-0.22^{\mathrm{NS}}$ \\
GW1 & $0.20^{\mathrm{NS}}$ & $0.28^{\mathrm{NS}}$ & $0.12^{\mathrm{NS}}$ & $0.56^{* *}$ & $0.56^{* *}$ & $0.01^{\mathrm{NS}}$ & $0.64^{* *}$ & & $-0.65^{* *}$ & $-0.38^{\mathrm{NS}}$ \\
BLW2 & $0.02^{\mathrm{NS}}$ & $0.15^{\mathrm{NS}}$ & $0.05^{\mathrm{NS}}$ & $0.19^{\mathrm{NS}}$ & $0.14^{\mathrm{NS}}$ & $0.02^{\mathrm{NS}}$ & $0.09^{\mathrm{NS}}$ & $0.25^{\mathrm{NS}}$ & & $0.10^{\mathrm{NS}}$ \\
GW2 & $-0.06^{\mathrm{NS}}$ & $-0.12^{\mathrm{NS}}$ & $0.27^{\mathrm{NS}}$ & $-0.12^{\mathrm{NS}}$ & $-0.18^{\mathrm{NS}}$ & $-0.27^{\mathrm{NS}}$ & $0.04^{\mathrm{NS}}$ & $0.03^{\mathrm{NS}}$ & $-0.17^{\mathrm{NS}}$ & \\
\hline
\end{tabular}

$\dagger \mathrm{PH}=$ plant height, $\mathrm{PPP}=$ pods per plant, $\mathrm{SPP}=$ seeds per pod, $\mathrm{BY}=$ biomass yield, $\mathrm{SY}=$ seed yield, TSW = thousand seed weight, $\mathrm{BLW} 1$ \& GW1 = dry weight of broad-leaf and grass weeds at weeding, respectively; BLW2 \& GW2 = dry matter of broad-leaf and grass weeds at harvesting

${ }^{* * * * * * * *}$ Significant at $P \leq 0.05, P \leq 0.01$ and $P \leq 0.001$, respectively; NS $=$ Not significant.

2). Higher coefficients of variations (CV) were obtained for seed and biomass yields of faba bean at Welmera than Rob Gebeya which is an indication of higher variability in less fertile environment. The results of this study showed a greater yield response to weeding at Welmera than at Rob Gebeya. This differential yield response could mainly be attributed to differences in weed flora and density in the two locations under the influence of seedbed preparation, soil fertility, crop rotation and the management of preceding crop. Results of different investigations also indicated that weed control operation at the proper growth stages of plants significantly increased mean seed yield and major yield components of faba bean (Fessehaie, 1986; Berhe et al., 1990; Ghizaw et al., 2000).

Full-season weed competition caused yield reduction up to $24 \%$ in faba bean in which the presence of weeds during the first 4,7 and 10 weeks after sowing accounted for respective yield reduction of 13.1, 15.9 and $22.2 \%$ (Fessehaie, 1994). Similarly, Kukula et al. (1985) and Knott and Halila (1988) have reported that substantial faba bean seed yield reduction was recorded due to weed competition. Seed yield was significantly correlated with dry matter of broad-leaf and grass weeds $\left(\mathrm{r}=0.61^{* *}\right.$ and $0.56^{* *}$, respectively) at Rob Gebeya, but not correlated at Welmera at weeding, while at harvesting the same parameter was not correlated at Rob Gebeya, but negatively correlated $\left(\mathrm{r}=-0.48^{*}\right)$ with broad-leaf weeds and not correlated with grass weeds at Welmera (Table 4). This shows that as the weed biomass decreased the seed yield of faba bean increased and positively correlated with weed biomass and vice versa.

\subsection{Economic analysis}

As farmers attempt to evaluate the economic benefits of shift in practice, partial budget analysis was done to identify the rewarding treatments. Yield from on-farm experimental plots was adjusted downward by $15 \%$ i.e., $10 \%$ for management difference and 5\% for plot size difference, to reflect the difference between the experimental yield and the yield that farmers could expect from the same treatment. Three years average market grain price of faba bean (ETB $1.60 \mathrm{~kg}^{-1}$ ), farm-gate price of $\mathrm{P}$ fertilizer (ETB $3.4 \mathrm{~kg}^{-1}$ ) and labour valued at ETB 5.5 per person-day were used. Labour for faba bean weeding was 39 person-days per hectare.

According to the results of partial budget analysis, the highest net benefit was obtained from the application of $20 \mathrm{~kg} \mathrm{P}^{-1}$ with weeding once six weeks after crop emergence (Table $6)$. The net benefit obtained by the control treatment (no weeding and no fertilizer applied) was ETB $1586.9 \mathrm{ha}^{-1}$. The net benefit increased proportionally for the increment in the total costs that vary up to the treatment with weeding once and application of $30 \mathrm{~kg} \mathrm{P} \mathrm{ha}^{-1}$ (P3/W1). According to dominance analysis, treatments with no fertilizer application and weeding once 
Agegnehu G., Fessehaie R.

Table 6. Partial budget and dominance Analyses of phosphorous rate and weed control treatments.

\begin{tabular}{|c|c|c|c|c|c|c|c|c|}
\hline \multirow[t]{2}{*}{ Treatments } & \multirow{2}{*}{$\begin{array}{c}\text { Average } \\
\text { yield } \\
\left(\mathrm{kg} \mathrm{ha}^{-1}\right)\end{array}$} & \multirow{2}{*}{$\begin{array}{c}\text { Adjusted } \\
\text { yield-15\% } \\
\left(\mathrm{kg} \mathrm{ha}^{-1}\right)\end{array}$} & \multirow{2}{*}{$\begin{array}{c}\text { Gross } \\
\text { benefits } \\
\left.\text { (ETB ha }{ }^{-1}\right)\end{array}$} & \multicolumn{3}{|c|}{ Costs that vary $\left(\right.$ ETB ha $\left.{ }^{-1}\right)$} & \multirow{2}{*}{$\begin{array}{c}\text { Net } \\
\text { benefits }\end{array}$} & \multirow[t]{2}{*}{ Dominance } \\
\hline & & & & Fertilizer & Labour & Total cost & & \\
\hline $\mathrm{P} 0 / \mathrm{W} 0$ & 1169 & 993.7 & 1586.9 & - & - & - & 1586.86 & \\
\hline $\mathrm{P} 0 / \mathrm{W} 1$ & 1353 & 1150.1 & 1836.6 & - & 214.5 & 214.50 & 1622.13 & Dominated \\
\hline $\mathrm{P} 1 / \mathrm{W} 0$ & 1381 & 1173.9 & 1874.6 & 168.2 & - & 168.19 & 1706.45 & \\
\hline $\mathrm{P} 1 / \mathrm{W} 1$ & 1643 & 1396.1 & 2230.3 & 168.2 & 214.5 & 382.69 & 1847.60 & \\
\hline $\mathrm{P} 2 / \mathrm{W} 0$ & 1544 & 1312.4 & 2095.9 & 336.4 & - & 336.37 & 1759.53 & Dominated \\
\hline $\mathrm{P} 2 / \mathrm{W} 1$ & 2015 & 1712.8 & 2735.3 & 336.4 & 214.5 & 550.87 & 2184.39 & \\
\hline $\mathrm{P} 3 / \mathrm{W} 0$ & 1683 & 1430.6 & 2284.6 & 504.6 & - & 504.56 & 1780.03 & Dominated \\
\hline $\mathrm{P} 3 / \mathrm{W} 1$ & 2181 & 1853.8 & 2960.6 & 504.6 & 214.5 & 719.06 & 2241.54 & \\
\hline
\end{tabular}

$\ddagger \mathrm{P} 0=$ No P, P1 = $10 \mathrm{~kg} \mathrm{P} \mathrm{ha}^{-1}, \mathrm{P} 2=20 \mathrm{~kg} \mathrm{P} \mathrm{ha}^{-1}, \mathrm{P} 3=30 \mathrm{~kg} \mathrm{P}^{-1} ; \mathrm{W} 0=$ Unweeded, W1 = Once weeded

"ETB = Ethiopian Birr; \$1USD = ETB 8.69.

Table 7. Marginal Analysis of weeding vs. phosphorous rate treatments.

\begin{tabular}{lccccc}
\hline Treatments $\ddagger$ & $\begin{array}{c}\text { Total cost } \\
\text { that vary }\end{array}$ & $\begin{array}{c}\text { Marginal } \\
\text { Cost }\end{array}$ & $\begin{array}{c}\text { Net } \\
\text { Benefit }\end{array}$ & $\begin{array}{c}\text { Marginal } \\
\text { benefit }\end{array}$ & $\begin{array}{c}\text { MRR } \\
(\%)\end{array}$ \\
\hline P0/W0 & 0 & - & 1586.9 & - & 71.1 \\
P1/W0 & 168.2 & 168.2 & 1706.5 & 119.6 & 65.8 \\
P1/W1 & 382.7 & 214.5 & 1847.6 & 141.2 & 200.3 \\
P2/W1 & 550.9 & 168.2 & 2184.4 & 336.8 & 34.0 \\
P3/W1 & 719.1 & 168.2 & 2241.5 & 57.2 & \\
\hline
\end{tabular}

$\$ \mathrm{P} 0=$ No $\mathrm{P}, \mathrm{P} 1=10 \mathrm{~kg} \mathrm{P} \mathrm{ha}^{-1}, \mathrm{P} 2=20 \mathrm{~kg} \mathrm{P} \mathrm{ha}^{-1}, \mathrm{P} 3=30 \mathrm{~kg} \mathrm{P}^{-1} ; \mathrm{W} 0=$ Unweeded, $\mathrm{W} 1$

(P0/W1), and with 20 and $30 \mathrm{~kg} \mathrm{P} \mathrm{ha}^{-1}$ and no weeding ( $\mathrm{P} 2 / \mathrm{W} 0$ and $\mathrm{P} 3 / \mathrm{W} 0)$ were dominated by other treatments, hence eliminated from further economic analysis (Table 6).

To identify treatments with maximum return to the farmers' investment, marginal analysis was performed on non-dominated treatments. For a treatment to be considered as a worthwhile option to farmers, the marginal rate of return (MRR) need to be at least between $50 \%$ and 100\% (CIMMYT, 1988). Researchers in other parts of the country suggested a MRR of $100 \%$ as realistic (Gorfu et al., 1991). Thus, for this study to make farmer recommendations from marginal analysis, $100 \%$ return to the investment is reasonable minimum acceptable rate of return since farmers in the study area usually neither weed nor apply fertilizer for faba bean. Accordingly, a treatment with application of 20 $\mathrm{kg} \mathrm{P} \mathrm{ha}{ }^{-1}$ and weeding once (P2/W1) are well above the minimum acceptable rate of return, $200.3 \%$ marginal rate of return (MRR). This implies that for ETB 1.0 investment in faba bean production, the producer can get ETB 1.0 and additional ETB 2.0 for treatment with $20 \mathrm{~kg} \mathrm{P} \mathrm{ha}{ }^{-1}$ (P2/W1) and weeding once. Therefore, since no farmer will prefer less return than the best al- ternative return, application of $20 \mathrm{~kg} \mathrm{P} \mathrm{ha}^{-1}$ and weeding once (P2/W1) is recommended as best economically rewarding treatment (Table 7).

\section{Conclusions}

Phosphorus fertilizer application and weed control significantly increased seed yields of faba bean. Although both factors had a positive effect on yields of faba bean at both locations, the influence of $\mathrm{P}$ fertilizer was more at Rob Gebeya than at Welmera. This is because the $\mathrm{pH}$ value and $\mathrm{P}$ content of the soil at Rob Gebeya were better than the values at Welmera. Hence, in order to produce satisfactory yield the soil acidity needs to be ameliorated using organic and inorganic sources of materials. Conversely, weed control had by far a more significant effect on yields of faba bean at Welmera than Rob Gebeya. Timely weeding could also enhance efficient utilization of applied fertilizer by plants. Therefore, considering the fertility status of the soil, $20 \mathrm{~kg} \mathrm{P} \mathrm{ha}^{-1}$ and weeding once six weeks after crop emergence can be recommended for faba bean production on Nitisols of similar areas of Ethiopian highlands. 


\section{Acknowledgements}

The Highland Food Legumes Project, sponsored by the Royal Netherlands Government, is highly acknowledged for funding this experiment. We are also thankful to Mr. Beyene Ofa and Mr. Badege Gebre, the staffs of Agronomy and Cop Physiology Research Division of Holetta Agricultural Research Center, for their assistance in the execution of the field experiment.

\section{References}

Agegnehu G., Sommer K. 2000. Optimization of the efficiency of phosphate fertilizers in acidic-ferralitic soils of the humid tropics. Ethiop. J. Natur. Resource, 2:63-77.

Agegnehu G., Ghizaw A., Yirga C. 2003. Response of faba bean and field pea to phosphate fertilizer on farmers' fields on Nitisols of Welmera Wereda, west Shewa. In: Amede T., Zewdie E. (eds.): Proceedings of the $6^{\text {th }}$ ESSS conference, Feb. 28 - Mar. 1, 2002. Ethiopian Society of Soil Science, Addis Ababa, Ethiopia, 13-24.

Bekele T., Höfner W. 1993. Effects of different P-fertilisers on yield of barley and rapeseed on reddish brown soils of the Ethiopian highlands. Fertiliser Res., 34:243-250.

Berhe A., Beniwal S.P.S., Ghizaw A., Telaye A., Beyene H., Saxena M.C. 1990. On-farm evaluation of four management factors for faba bean production in the Holetta zone of Shewa. Ethiop. J. Agric. Sci., 12:1728.

CIMMYT 1998. From agronomic data to farmer recommendations: Economics training manual. Completely revised ed. CIMMYT, Mexico, D.F.

Cooke G.W. 1986. Fertilizing for maximum yield. Third edition, Mackays of Khatham Ltd., Kent Publishers, U.K.

Fessehaie R. 1986. A review of weed science research activities in pulses in Ethiopia. In: Abate T. (ed.): Proceedings of the $1^{\text {st }}$ crop protection symposium, 4-7 Feb., 1985, IAR, Addis Ababa, Ethiopia, 403-420.

Fessehaie R. 1994. Weed research in cool season food legumes. In: Telaye A., Bejiga G., Saxena M.C., Solh M.B. (eds.): Cool-season food legumes of Ethiopia. Proceedings of the $1^{\text {st }}$ National Cool-season Food Legumes Review Conference, 16-20 December, 1993, Addis Ababa, Ethiopia. ICARDA/IAR. ICARDA: Aleppo, Syria, 252-275.

Ghizaw A., Molla A. 1994. Faba bean and field pea agronomy research. In: Telaye A., Bejiga G., Saxena M.C., Solh M.B. (eds.): Cool-season food legumes of Ethiopia. Proceedings of the $1^{\text {st }}$ National Cool-season Food Legumes Review Conference, 16-20 December, 1993, Addis Ababa, Ethiopia. ICARDA/IAR. ICARDA: Aleppo, Syria, 199-229.

Ghizaw A., Mamo T., Yilma Z., Molla A., Ashagre Y. 1999. Nitrogen and phosphorus effects on faba bean yield and some yield components. J. Agron. Crop Sci., 182:167-174.

Ghizaw A., Beniwal S.P.S, Mekonnen D., Woldemariam M., Saxena M.C. 2000. Relative importance of some management factors on faba bean. Ethiop. J. Agric. Sci, 17:17-31.

Gorfu A., Taa A., Tanner D.G., Mwangi W. 1991. Onfarm research to derive fertilizer recommendations for small-scale bread wheat production: methodological issues and technical results. Research report no. 14. IAR, Addis Ababa, Ethiopia.

Hebblethwaite P.D., Hawtin G.C., Latman P.J.W. 1983. The husbandry of establishment and maintenance. In: Hebblethwaite P.D. (ed.): Faba bean (Vicia faba L.): A basis for improvement, 271-312. Cambridge University Press, UK.

Hocking P.J., Keerthisinghe G., Smith F.W., Randall P.J. 1997. Comparison of the ability of different crop species to access poorly available soil phosphorus. In: Ando T., Fujita K., Mae T., Matsumoto H., Mori S., Sekiya J. (eds.): Plant nutrition-for sustainable food production and environment, 305-308. Kluwer Academic Publishers, Japan.

Knott C.M., Halila H.M. 1988. Weeds in food legumes: Problems, effect and control. In: Summerfield R.J. (ed.): World Crops: Cool-season food legumes, 535548. Kluwer Academic Publisher, Dordrecht, the Netherlands.

Kukula S., Haddad A., Masri H. 1985. Weed control in lentils, faba bean, and chickpeas. In: Saxena M.C., Varma S. (eds.): Proceedings of Faba Beans, Kabuli Chickpeas, and Lentils in the 1980s. ICARDA, Aleppo, Syria, 169-177.

Leon L.A., Le Mare P.H. 1990. Effects of residues of triple-super-phosphate on the quantity-intensity relationship of fresh phosphate in some soils from Brazil and Colombia. Fert. Res., 2:159-166.

Mahler R.L., Saxena M.C., Aeschlimann J. 1988. Soil fertility requirements of pea, lentil, chickpea and faba bean. In: R.J. Summerfield (ed.): World crops: Cool season food legumes. Proceedings of the International Food Legumes Research Conference on Pea, Lentil, Faba Bean and Chickpea. Washington, USA, 6-11 July, 1986, 279-289.

Marschner H. 1995. Mineral nutrition of higher plants. Academic Press, Harcour Brace Jovanovich Publishers, London.

SAS Institute Inc. 2001. SAS/STAT user's guide, version 8.2, SAS Inst., Cary, NC.

Schubert E., Mengel K., Schubert S. 1990. Soil pH and calcium effects on nitrogen fixation and growth of broad bean. Agron. J., 82:969-972.

Sharma P.K., Verma T.S., Gupta J.P.,1990. Ameliorating effects of phosphorus, lime and animal manure on wheat yield and root cation exchange capacity in degraded Alfisols of North-West Himalayas. Fertilizer Res., 23:7-13. 
Sikora F.J., Copeland, J.P., Mullins G.L., Bartos J.M. 1991. Phosphorus dissolution kinetics and bio-availability of water insoluble fractions from mono-ammonium phosphate fertilizers. Soil Sci. Soc. Am. J., 53:362-368.

Tsigie A., Woldeab A. 1994. Fertiliser response trials on highland food legumes. In: Telaye A., Bejiga G., Saxena M.C., Solh M.B. (eds.): Cool-season food legumes of Ethiopia. Proceedings of the $1^{\text {st }}$ National Cool-season Food Legumes Review Conference, 16-20 December, 1993, Addis Ababa, Ethiopia. ICARDA/AR. ICARDA: Aleppo, Syria, 279-292. 